\title{
Erratum to : La diaphyse fémorale AL 333-61 : preuve d'une bipédie comme unique mode locomoteur il y a 3,2 Ma en Ethiopie ?
}

Eratum to: AL 333-61 femoral diaphysis: evidence of obligate bipedalism 3.2 million years ago in Ethiopia?

\author{
T. Chevalier \\ (C) Société d'anthropologie de Paris et Springer-Verlag France 2013
}

Erratum to: Bull. Mém. Soc. Anthropol. Paris DOI 10.1007/s13219-012-0074-2

Dans cet article, la légende de la figure 7 était incomplète, nous la republions ici (Fig. 1).

T. Chevalier $(\bowtie)$

EPCC-CERP (Centre Européen de Recherches Préhistoriques),

Avenue Léon-Jean Grégory, 66720 Tautavel

e-mail : tony.chevalier@cerptautavel.com 


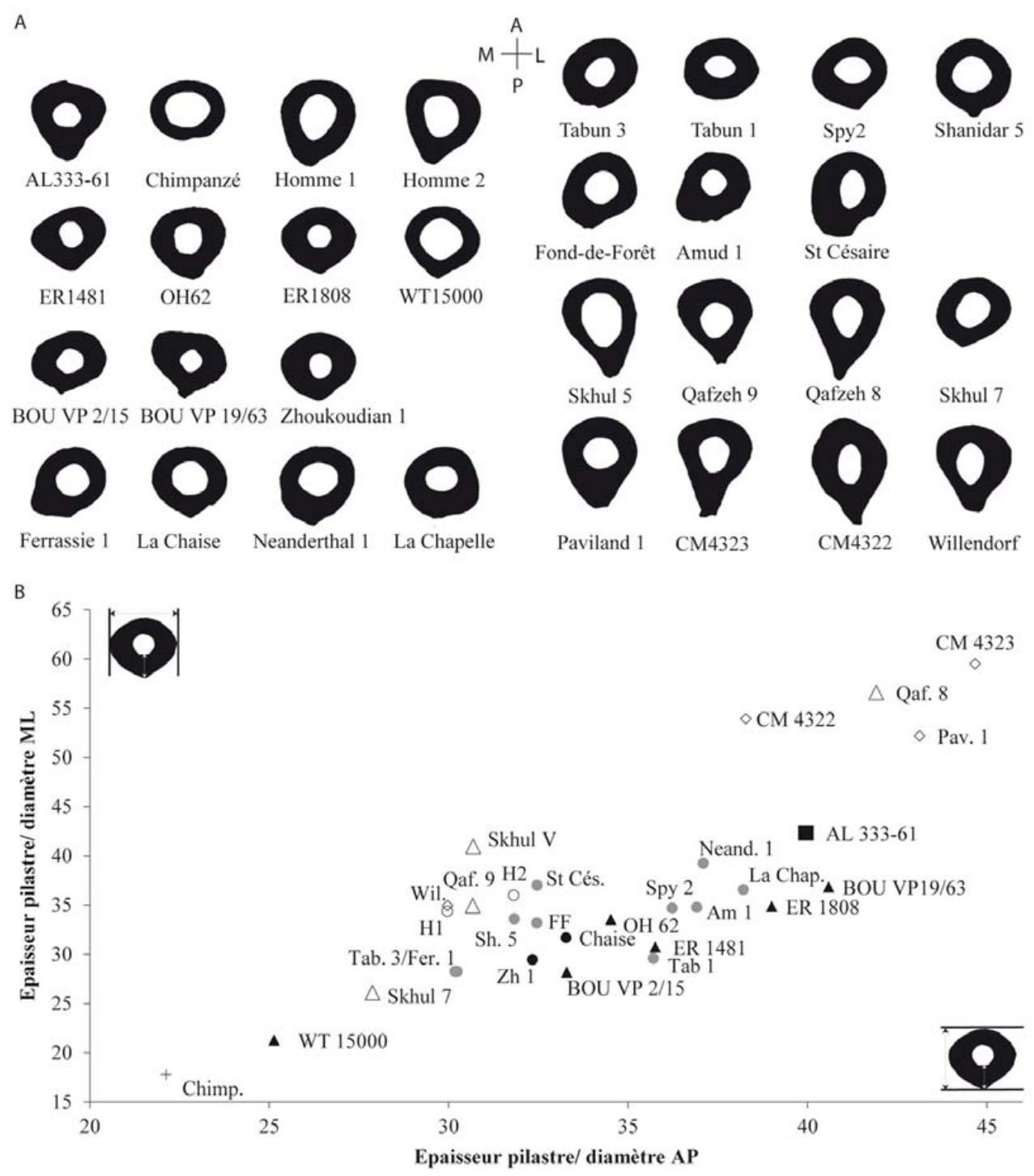

Fig. 1 Fig. 7. A- Section transversale à $50 \%$ de la longueur biomécanique (exceptée pour Bouri). Les sections sont présentées avec la même largeur et la même latéralité. Les sections transversales (modifiées par l'auteur pour les homogénéiser) proviennent de : Chimpanzé, Homme 1, OH62, KNMER 1808, WT 15000 [1] ; Homme 2, KNM ER 1481, Zhoukoudian 1, La Chapelle-aux-Saints, Paviland 1 [2] ; Ferrassie 1, Neanderthal 1, CM4323, CM4322, Spy 2, Paviland 1 [3] ; La Chaise [4] ; Tabun 3, Tabun 1, Shanidar 5, Amud 1, Skhul 5, Qafzeh 9, Qafzeh 8, Skhul 7 [5] ; Fond-de-Forêt, Spy 2 [6] ; St Césaire [7] ; BOU VP 2/15, BOU VP 19/63 [8] ; Willendorf [9]. B- Epaisseur corticale relative du pilastre pour le même échantillon / A- Femoral midshaft cross-sections (except for Bouri). The cross-sections are scaled to the same width and laterality. Cross-sectional morphology (modified for homogeneity) from : Chimpanzé, Homme 1, OH62, KNMER 1808, WT 15000 [1]; Homme 2, KNM ER 1481, Zhoukoudian 1, La Chapelle-aux-Saints [2]; Ferrassie 1, Neanderthal 1, CM4323, CM4322, Spy 2, Paviland 1 [3]; La Chaise [4]; Tabun 3, Tabun 1, Shanidar 5, Amud 1, Skhul 5, Qafzeh 9, Qafzeh 8, Skhul 7 [5]; Fond-de-Forêt [6]; St Césaire [7]; BOU VP 2/15, BOU VP 19/63 [8]; Willendorf [9]; B-Relative cortical bone thickness of the pilaster in same sample. 


\section{Références}

1. Ruff CB (2009) Relative limb strength and locomotion in Homo habilis. Am J Phys Anthropol 138:1139-44

2. Ruff CB, Trinkaus E, Walker A, et al (1993) Postcranial robusticity in Homo. I: temporal trends and mechanical interpretation. Am J Phys Anthropol 91:21-53

3. Trinkaus E (1997) Appendicular robusticity and the paleobiology of modern human emergence. Proc Natl Sci USA 94: $13367-73$

4. Condemi S (2001) Les néandertaliens de la Chaise. Comité des travaux historiques et scientifiques. $178 \mathrm{p}$
5. Trinkaus E, Ruff CB (1999) Diaphyseal cross-sectional geometry of the near eastern middle Palaeolithic humans: the femur. J Arch Sci 26:409-24

6. Trinkaus E, Ruff CB (1989) Diaphyseal cross-sectional morphology and biomechanics of the Fond-de-Forêt 1 femur and the Spy 2 femur and tibia. Anthropologie et Préhistoire 100:33-42

7. Trinkaus E, Churchill SE, Ruff CB, et al (1999) Long bone shaft robusticity and body proportions of the Saint-Césaire 1 châtelperronian Neanderthal. J Arch Sci 26:753-73

8. Gilbert WH, Asfaw B (2008) Homo erectus, Pleistocene evidence from the Middle Awash, Ethiopia, University of California Press, $458 \mathrm{p}$

9. Teschler-Nicola M, Trinkaus E (2001) Human remains from the Austrian gravettian: the Willendorf femoral diaphysis and mandibular symphysis. J Hum Evol 40:451-65 